\title{
Masyarakat Depok Memilih Fogging yang Tidak Dimengerti
}

\section{Tri Krianto*}

\begin{abstract}
Abstrak
Sampai kini, demam berdarah dengue masih menjadi masalah kesehatan yang utama di Kota Depok. Hal tersebut terlihat pada jumlah kasus yang terus meningkat dan semua kelurahan sudah berkembang menjadi daerah endemis demam berdarah dengue yang dapat dicegah dengan mengendalikan vektor. Upaya pembersihan sarang nyamuk PSN 3M Plus adalah teknologi yang disarankan untuk mengendalikan kejadian demam berdarah dengue, tetapi belum mendapat dukungan pelaksanaan dari masyarakat. Studi ini bertujuan untuk menggali informasi tentang pengetahuan, sikap dan praktek masyarakat dalam pengendalian vektor demam berdarah dengue di Kota Depok. Hasil studi menunjukkan bahwa pengetahuan dan partisipasi masyarakat dalam pengendalian vektor DBD masih rendah, dan lingkungan sosial berpengaruh sangat dominan terhadap keputusan masyarakat.

Kata kunci : Demam berdarah, pengendalian vektor, promosi kesehatan

\section{Abstract}

Until now, dengue hemorrhaegic fever (DHF) is the major health problem in Depok City, number of cases was increasing, and nowadays all sub-district have DHF endemic areas. DHF can be prevented by vector control. PSN 3M Plus is the recommended technology, but the community has not been implemented it yet. This study aims to explore information about knowledge, attitude and practice in dengue control among the communities. Results of this study indicated that knowledge and community participation dengue vector control were still low, and social environment factor was the dominant factor influencing community decision.
\end{abstract}

Key words : Dengue, vector control, health promotion 
Kota Depok yang terkenal sebagai kota pelajar dan mahasiswa utama di Provinsi Jawa Barat sekaligus menjadi salah satu penyangga penduduk Kota Jakarta masih dihadapkan pada masalah pengendalian penyakit Demam Berdarah Dengue (DBD). Berdasarkan data Dinas Kesehatan Kota Depok, kejadian demam berdarah memperlihatkan kecenderungan yang terus meningkat. Dalam kurun waktu tahun 2006 - 2007, jumlah kasus DBD melonjak dari 1838 kasus menjadi 2956 kasus $(63 \%)$. Kini, seluruh kelurahan yang berada di wilayah Kota Depok yang berjumlah 63 telah berada pada kategori endemis demam berdarah dengue. Berdasarkan analisis tren lima tahun ke depan, rerata terjadi pergeseran kasus setiap tiga tahun, hingga tahun 2012, kasus DBD di Depok diprediksi berada pada kisaran 20002500 kasus per tahun.

Secara ekonomis, jumlah kejadian kasus yang besar tersebut sangat merugikan masyarakat dan pemerintah kota. Dengan memperhitungkan besar pengeluaran dan kerugian minimum rumah tangga akibat demam berdarah, jumlah uang yang hilang berada pada kisaran Rp. 8 milyar - Rp. 15 milyar per tahun. Sekitar 30\% (1000) anak-anak usia sekolah paling tidak akan kehilangan sepuluh hari belajar mereka. Apabila dalam satu tahun tersedia 250 hari belajar, maka besar kerugian yang disebabkan oleh BDB tersebut mencapai $4 \%$. Berbagai kerugian lain meliputi kerugian psikologis, sosial, bahkan yang terberat adalah kematian. Pada tahun 2007, jumlah penderita DBD yang meninggal dunia dapat mencapai 14 orang.

Penyakit ini dapat dicegah dengan cara melakukan eradikasi vektor nyamuk Aedes aegypt di lingkungan rumah tangga. Kampanye upaya pencegahan demam berdarah dilakukan pemerintah melalui program pengendalian vektor yang disebut pemberantasan sarang nyamuk dengan 3M Plus (PSN 3M Plus). Upaya tersebut meliputi menutup tempat penampungan air, menguras dan menyikat bak mandi atau tempayan, mengubur barang bekas, mencegah gigitan nyamuk dengan menggunakan repelen, menaburkan bubuk larvasida, dan memelihara ikan pemangsa jentik. Pemerintah Kota Depok juga melakukan beberapa upaya pengendalian vektor antara lain dengan melatih kader pemeriksa jentik.

Meskipun demikian, angka kasus DBD masih memperlihatkan kecenderungan yang tetap tinggi. Diperkirakan masih banyak warga Depok tidak melakukan PSN 3M Plus seperti yang diharapkan, sehingga jentik nyamuk dan habitat potensial masih banyak ditemukan. Praktik warga yang rendah diduga berhubungan dengan banyak faktor antara lain pengetahuan yang rendah, anggapan DBD bukan masalah serius, ketidaktahuan pihak yang bertanggung jawab serta alasan lain seperti ekonomi. Studi di Taiwan Selatan, pada tahun 2002, menemukan bahwa hanya sekitar 57,4\% responden yang mengetahui tempat perkembangbiakan jentik nyamuk Aedes aegypti. ${ }^{1}$ Selain itu, banyak anggota masyarakat menganggap bahwa pemberantasan sarang nyamuk bukan tanggung jawab mereka, tetapi tanggung jawab pemerintah. Sekitar 56,8\% responden menyatakan bahwa pencegahan penyakit yang ditularkan melalui gigitan nyamuk tersebut adalah tanggung jawab pemerintah. ${ }^{2}$ Suatu studi menjelaskan bahwa kepatuhan terhadap program PSN 3M berimplikasi terhadap biaya yang harus dikeluarkan oleh masyarakat. Misalnya, menguras bak mandi tentu berimplikasi pada biaya pembelian air bersih yang menjadi hambatan pada penduduk miskin. ${ }^{3}$

Secara konvensional, upaya kampanye yang intensif dapat meningkatkan kesadaran, pengetahuan, sikap dan praktek kelompok sasaran. Namun, jika upaya kampanye tidak berhasil meningkatkan pengetahuan hingga praktek sasaran, maka beberapa pertanyaan mendasar patut diajukan, antara lain adalah: Apakah kampanye sudah dilakukan secara menyeluruh pada masyarakat Depok? Apakah terjadi penapisan yang ketat sehingga kampanye yang intensif tidak diikuti oleh praktek yang memadai? Artikel ini menyajikan gambaran perilaku masyarakat dalam mengendalikan vektor demam berdarah dengue, meliputi pengetahuan, sikap, praktek, serta kontributornya.

\section{Metode}

Studi eksplorasi ini dilakukan dengan pendekatan kualitatif. Populasi adalah sebagian masyarakat Kota Depok yang tinggal di wilayah Kecamatan Sukmajaya dan Kecamatan Limo. Sumber informasi yang dipilih meliputi kepala keluarga dan ibu rumah tangga, petugas puskesmas, tokoh masyarakat, dan pengelola program di tingkat kota. Data dikumpulkan melalui wawancara mendalam (WM) dengan tokoh masyarakat (TM), pengelola program (PP) dan petugas puskesmas (PKM). Sedangkan, terhadap dua kelompok rumah tangga (RT) yang meliputi kepala keluarga dan ibu rumah tangga dilakukan diskusi kelompok terarah (DKT). Pengamatan (O) dilakukan terhadap praktek masyarakat dalam PSN (Lihat Tabel 1).

Pengumpulan data dilakukan dalam periode sekitar tiga minggu, mulai minggu ke 4 bulan Mei hingga minggu ke 2 bulan Juni tahun 2007. Kehadiran dan respon para narasumber cukup baik. Dalam pelaksanaan diskusi kelompok terarah, kehadiran para ibu yang diundang $(100 \%)$ lebih besar daripada kehadiran pada bapak $(75 \%)$. Semua narasumber bersedia memberikan keterangan yang diminta pada wawancara mendalam. Sebelum melakukan pengumpulan data, dimintakan persetujuan (informed consent) terhadap calon narasumber untuk mengikuti kegiatan pengumpulan data. Informasi 
Tabel 1. Matriks Tujuan Khusus, Informasi yang Dibutuhkan, Sasaran dan Teknik.

\begin{tabular}{llll}
\hline Tujuan Khusus & Informasi yang Dibutuhkan & Sasaran & Teknik \\
\hline \multirow{2}{*}{ Pengetahuan } & Penyebab penyakit & RT & DKT \\
& Cara pencegahan & RT & DKT \\
\multirow{3}{*}{ Persepsi } & Program pencegah pemerintah & RT+PKM+PP & DKT+WM \\
& Keseriusan penyakit & RT & DKT \\
& Kerentanan & RT & DKT \\
& Manfaat PSN & RT & DKT \\
\multirow{5}{*}{ Sikap } & Kesulitan melakukan PSN & RT+PKM+TM & DKT+WM+WM \\
\multirow{2}{*}{ Tindakan } & Pengasapan \& abatisasi & RT+PKM & DKT+WM \\
& PSN & RT+PKM+PP & DKT+WM \\
& Pernah melakukan PSN & RT & DKT \\
Faktor lain & Kebiasaan melakukan PSN & RT+PKM & DKT+WM+O \\
& Gerakan masyarakat dlm PSN & TM & WM+O \\
& Penyebab tidak melakukan PSN & RT+PKM+TM+PP & DKT+WM+WM \\
\hline
\end{tabular}



Gambar 1. Asumsi Perilaku Masyarakat Mengendalikan Vektor

yang diperoleh diolah dan dianalisis melalui: a) transkripsi non verbatim, b) pengembangan matriks analisis, c) melakukan analisis isi (content analysis), d) melakukan triangulasi sumber informasi dan metode.

\section{Hasil}

\section{Karakteristik Informan}

Secara umum informan dalam kegiatan ini terdiri dari dua kelompok yang meliputi kelompok profesional yang terdiri dari pejabat, pengelola program serta petugas dan kelompok awam yang meliputi kader dan anggota masyarakat. Kelompok profesional yang umumnya berpendidikan S1 ke atas mempunyai latar belakang kesehatan, pemerintahan dan sosial ekonomi pertanian. Kelompok awam bapak-bapak umumnya berpendidikan SLTA sampai D3 dengan profesi yang beragam, sedangkan informan ibu berpendidikan SMP sampai SLTA, dan umumnya tidak bekerja.

\section{Model yang Dinilai}

Dalam teori perilaku belajar, perubahan perilaku populer mengikuti sistematika pengetahuan, sikap, dan praktek. ${ }^{4}$ Pengetahuan mendahului sikap, selanjutnya sikap diikuti oleh perilaku. Meskipun demikian, berdasarkan penelitian lain, diperoleh informasi bahwa pengetahuan yang tinggi tidak selalu diikuti oleh sikap yang positif dan praktek yang baik. Alur berpikir penulisan terkait penelitian ini diilustrasikan pada Gambar 1.

Pada penelitian ini, asumsi yang digunakan meliputi: a) Masyarakat mengetahui akibat dan penyebab DBD serta metode pencegahan dan manfaat PSN 3M Plus. b) Apabila persepsi tentang manfaat dan cara pencegahan positif, seharusnya sikap terhadap PSN 3M juga positif. c) Jika sikap positif, maka kegiatan PSN 3M dilakukan oleh masyarakat. d) Namun, jika persepsi kurang baik, pengetahuan yang baik diikuti sikap yang tidak positif. e) Ada kemungkinan sikap positif, tetapi tidak melakukan PSN 3M karena ada faktor lain.

\section{Pengetahuan Masyarakat}

Secara umum pengetahuan masyarakat tentang DBD masih rendah. Pada ibu yang menjadi informan belum dapat menjelaskan penyebab DBD, sebagian besar menyebutkan bahwa DBD terjadi karena kondisi yang lemah, kurang menjaga kebersihan dan salah pergaulan, sehingga mudah terjangkit DBD. Dengan demikian, terlihat bahwa pengetahuan ibu tentang penyebab DBD 
masih sangat rendah. Hal yang hampir sama juga ditemukan di kalangan bapak-bapak. Meskipun mereka tahu bahwa penyebab DBD adalah nyamuk Aedes aegypti, tetapi tempat perindukkannya tidak diketahui, mereka menyatakan koya sebagai tempat perindungan tersebut. Padahal, koya adalah suatu lubang yang biasanya digali pada sebidang tanah di lahan pekarangan atau kebun, yang digunakan untuk menampung limbah rumah tangga.

“...koya...itu kan tempat menampung limbah...jadi ya kalau ada airnya maka nyamuk aedes jentiknya bisa disitu...".

Menurut informan puskesmas, koya tidak bisa menjadi tempat perkembangbiakan Ae.aegypti karena dinding dan lantainya tanah. Informan puskesmas justru menambahkan bahwa kebiasaan masyarakat membuang sampah, termasuk di antaranya botol bekas ke pekarangan atau kebun kosong yang menyebabkan banyaknya kejadian demam berdarah.

“...Justru yang banyak orang buang sampah yang bisa nampung air ke kebon kosong, misalnya bekas gelas atau botol aqua, styrofoam habis makan bakso dan sebagainya...”.

Berbagai penelitian membuktikan bahwa Pemberantasan Sarang Nyamuk (PSN) adalah metode pencegahan DBD yang paling efektif. Metode ini sudah lama diperkenalkan kepada masyarakat. Kampanye praktek 3M dimulai sekitar tahun 1990-an. Namun, studi ini menunjukkan bahwa pengetahuan masyarakat tentang metode PSN 3M Plus masih sangat rendah. Sebagian besar ibu menyatakan pengasapan, sebagian lainnya menyebut tentang kebersihan lingkungan. Informasi 3M pernah didengar, tetapi ketika ditanyakan perihal kepanjangannya, semua ibu peserta diskusi berpikir keras untuk mengingatnya. Satu M saja yang diingat yaitu menguras, namun $\mathrm{M}$ yang lainnya tidak dapat diingat.

\section{Persepsi Keseriusan DBD}

DBD merupakan masalah kesehatan masyarakat prioritas Pemerintah Kota Depok. Menurut Kepala Dinas Kesehatan, walaupun berbagai upaya sudah dilakukan, tetapi frekuensi kasus DBD memperlihatkan kecenderungan yang terus meningkat.

"...Saya sendiri juga bingung, sudah ada PSN, fogging, penyuluhan dan sebagainya, tetapi kasusnya masih tinggi, wilayah yang banyak ditemukan kasus adalah Tugu, Cimanggis, dan Sukmajaya. Yang paling jarang itu Sawangan...”.

Pemerintah menilai masyarakat kurang serius menanggapi kejadian DBD yang terus meningkat. Perhatian masyarakat, terutama para bapak terhadap sosialisasi PSN 3M Plus sangat kurang. Menurut informan dari puskesmas walaupun penyuluhan dilakukan pada malam hari, respons para bapak yang hadir masih sangat rendah.

“...kalau ada pertemuan...ya kita usahakan datang malam hari...yang datang ya sedikit sekali...beda dengan ibu-ibu...mungkin waktunya ya...persis seperti sekarang ini...kalau ibu-ibu diundang biasanya 100 persen datang...tapi kalau bapak-bapak...wah sulit...”.

Berbeda dengan bapak-bapak, para ibu menilai bahwa DBD cukup serius dan dapat menimpa siapa pun. Demam tinggi dan bintik merah, serta pengalaman ada anggota keluarga yang mengalami perdarahan menyebabkan mereka memberikan perhatian khusus kepada masalah DBD. Padahal, dalam kegiatan pengendalian vektor, peran para bapak sangat diharapkan, apalagi ada pembagian kerja tingkat rumah tangga.

\section{Sikap Terhadap PSN 3M Plus}

Pengendalian vektor dengan PSN 3M Plus dianggap sebagai salah satu metode penanggulangan DBD yang tidak lebih penting daripada pengasapan. Informan dari kelurahan, tokoh masyarakat, kelompok bapak maupun kelompok ibu serta hasil dari pengamatan menunjukkan bahwa pengasapan dianggap sebagai metode utama. Kelompok bapak senantiasa menyampaikan pentingnya pengadaan mesin fogging.

“...Di sini banyak sekali yang terkena demam berdarah. Oleh karenanya kami berusaha dengan swadaya masyarakat agar punya mesin fogging...”.

Kepercayaan masyarakat yang kuat terhadap metode pengasapan juga ditunjukkan oleh jawaban "penyemprotan" atau pengasapan yang mengemuka untuk pertanyaan tentang metode mencegah kejadian demam berdarah.

\section{Tindakan Mencegah DBD}

Kebijakan pemerintah dalam menanggulangi DBD adalah pemberantasan sarang nyamuk (PSN), pengasapan (fogging), dan larvasidasi. Di Depok, fogging jauh lebih populer daripada PSN 3M Plus. Berdasarkan pengamatan, PSN bahkan tidak dilakukan oleh keluargakeluarga yang pernah berpengalaman kontak dengan DBD, seperti hasil pengamatan penulis terhadap 8 keluarga di kompleks perumahan " $X$ " di Kecamatan Sukmajaya. Pada tahun 2005, 6 orang warga terjangkit DBD yang terdiri dari 4 dewasa dan 2 anak. Ada satu kepala keluarga (KK) yang anak nomor 2 terkena, disusul ayahnya, dan ketika ayahnya belum sembuh, anak nomor tiga juga masuk rumah sakit karena DBD. Pada empat keluarga yang juga terpajan pada DBD tidak melakukan PSN. Padahal, di kompleks perumahan tersebut pada tahun 2005 ada lebih dari 8 orang yang terinfeksi dengue. Pada tahun 2006, 2 orang warga terkena DBD. Pada tahun 2007, ada 2 keluarga yang terkena DBD, dan tidak melakukan upaya-upaya pencegahan sama sekali.

“...Yang anggota keluarganya pernah kena DBD, jus- 


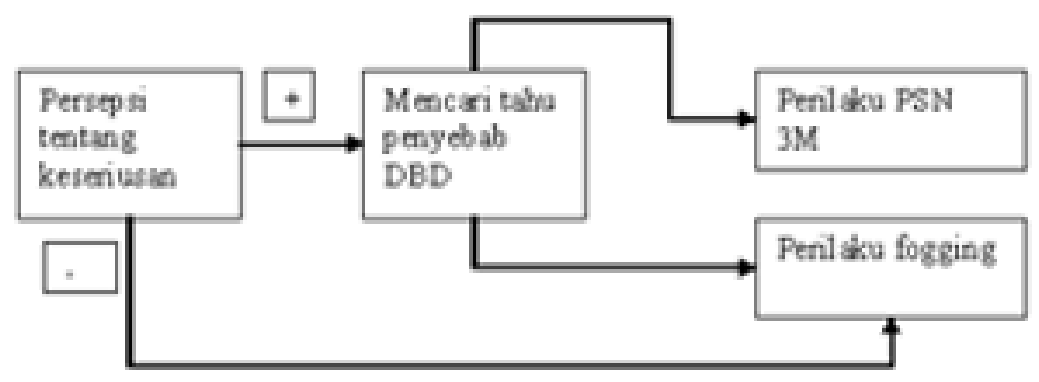

Gambar 2. Perilaku Masyarakat dalam Pengendalian Vektor

tru kadang-kadang saya lihat itu ya belum ada perubahan. Ya PSN nya itu yang belum. Kita bertahap. Kita memberikan gambaran PSN. Tetapi kelihatannya kalah pamor dibanding fogging...".

Berdasarkan pengamatan, warga di kompleks perumahan tersebut lebih antusias membayar petugas penyemprotan swasta daripada melakukan PSN 3M Plus. Apabila ada warga yang terkena DBD maka yang menjadi harapan masyarakat adalah segera dilakukan pengasapan. Apabila puskesmas tidak segera melakukan pengasapan, maka warga masyarakat berinisiatif mengumpulkan dana untuk mengundang petugas penyemprotan swasta. Meskipun demikian, ada seorang ibu yang meragukan komposisi bahan yang disemprotkan tersebut.

Tindakan PSN 3M Plus yang kurang lengkap antara lain berkaitan dengan pemahaman tentang kepanjangan $3 \mathrm{M}$ yang kurang. Pada umumnya yang diingat adalah menguras, namun setelah diberitahu bahwa $\mathrm{M}$ yang lain adalah menutup dan mengubur, para ibu mengakui bahwa menutup dan mengubur belum mereka lakukan. Mereka tidak menutup tempat-tempat penampungan atau yang dapat menampung air karena belum mengetahui. Sedangkan, tidak melakukan penguburan karena harus mencangkul, menggali yang lebih sesuai dilakukan oleh para suami.

Kebiasaan menyimpan barang bekas berhubungan dengan peluang untuk menukarkannya dengan perabotan rumah tangga. Beberapa ibu mengaku bahwa mereka mengumpulkan terlebih dahulu barang-barang bekas, untuk kemudian menukarnya dengan piring atau perabotan dapur yang lain.

\section{Keterpajanan dengan Informasi DBD}

Demam berdarah adalah informasi kesehatan yang penting bagi masyarakat Depok. Oleh sebab itu, akses informasi tentang DBD seharusnya diperluas. Namun, studi ini menunjukkan bahwa akses informasi masyarakat dalam DBD sangat kurang. Para informan mengaku memperoleh informasi hanya melalui televisi, sehingga jika ada yang tidak jelas mereka tidak tahu ke mana harus bertanya. Informan dari puskesmas juga mengatakan bahwa informasi tentang DBD yang diterima masyarakat sangat kurang. Apabila ada informasi biasanya hanya yang terkait hal-hal klinis, misalnya gejala maupun pengobatannya. Kampanye PSN 3M Plus belum dilakukan secara berkelanjutan.

"...Sementara ini pesannya kelihatannya hanya teknis. Hanya gejala, bagaimana pengobatannya...belum ada kampanye yang berkesinambungan tentang perlunya melakukan PSN...”.

Selain pada masyarakat, sosialisasi permasalahan dan pengendalian demam berdarah pada para camat dan lurah juga sangat kurang. Pihak puskesmas menilai pihak kecamatan belum sejalan dalam menanggulangi DBD. Puskesmas berpendapat bahwa PSN 3M Plus adalah cara terbaik mengendalikan vektor DBD, tetapi pihak kecamatan senantiasa meminta puskesmas melakukan fogging. Menurut informan dari puskesmas hal ini berkaitan dengan pemahaman camat mengenai DBD. Hal yang sama juga terjadi pada para lurah. Dalam beberapa kesempatan berdiskusi dengan para lurah, tampak bahwa mereka yakin bahwa penanggulangan BDB dapat dilakukan apabila di setiap kelurahan tersedia mesin fogging.

\section{Model yang Ditemukan}

Berdasarkan hasil studi ini diperoleh model yang lebih tepat dalam menggambarkan perilaku pengendalian vektor DBD pada rumah tangga di Kota Depok. Secara umum dikatakan bahwa perilaku masyarakat dalam pengendalian vektor DBD tidak tepat dan cenderung hanya mengikuti kebiasaan lingkungan. Masyarakat berperilaku inkonsisten dalam melakukan pengendalian vektor, serta mengutamakan pengasapan (fogging) untuk mencegah DBD. Pola pembentukan perilaku pengendalian vektor dapat dilihat pada Gambar 2.

Dalam menghadapi DBD, ada anggota masyarakat yang menanggap dengan serius dan ada pula yang tidak serius. Bagi yang serius biasanya berusaha mencari in- 
formasi yang lebih lengkap. Selanjutnya, mereka melakukan tindakan PSN atau menyemprot yang berkaitan dengan karakteristik sosial, ekonomi, dan budaya masyarakat. Namun, bagi yang tidak serius biasanya berpartisipasi dalam penyemprotan. Ketidaktepatan perilaku tersebut disebabkan oleh pengetahuan yang kurang serta persepsi yang keliru tentang tingkat keseriusan penyakit DBD.

\section{Pembahasan}

Studi ini menghasilkan 4 temuan, yaitu: a) pengetahuan masyarakat tentang penyebab demam berdarah, habitat perkembangbiakan vektor serta cara paling efektif untuk mengendalikannya masih rendah, b) belum terjadi kesepahaman tentang keseriusan dan cara yang seharusnya untuk mengendalikan DBD pada masyarakat maupun pada unsur pemerintahan setempat. Sehingga, partisipasi masyarakat dalam PSN 3M Plus terlihat sangat rendah, c) fogging lebih dipercaya daripada PSN 3M Plus, dan d) keberlanjutan perilaku pengendalian vektor rendah, karena masyarakat berperilaku bukan berdasarkan pengetahuan yang dimiliki, tetapi mengikuti kebiasaan lingkungan sosial mereka. Keempat hal tersebut terjadi karena promosi kesehatan dalam penanggulangan DBD belum terlaksana secara maksimal, koordinasi lintas sektor dan sosialisasi internal pemerintahan belum berjalan secara baik, dan keterbatasan para kepala keluarga dalam melaksanakan aktivitas PSN 3M Plus.

\section{Promosi Kesehatan yang Kurang}

Studi ini mengindikasikan pengetahuan masyarakat tentang DBD masih tergolong rendah. Hal ini mengejutkan karena masih sesuai dengan temuan Kasnodihardjo dan Sotomo, ${ }^{5}$ di Sukabumi pada 20 tahun silam, bahwa sikap masyarakat yang positif terhadap PSN kanya berkisar 48\%. Perilaku terbentuk karena kecukupan faktor pencetus, kesediaan faktor pemungkin, dan dorongan atau tekanan dari faktor penguat. ${ }^{6}$ Apabila hal tersebut diimplementasikan pada masalah perilaku PSN 3M, maka karakteristik sosial, budaya dan ekonomi masyarakat serta pengetahuan tentang DBD digolongkan sebagai faktor pencetus. Kesempatan mengikuti berbagai penyuluhan yang terbatas serta ketiadaan sumber informasi DBD merupakan faktor pemungkin. Pengaruh lingkungan sosial dalam mengambil keputusan PSN 3M Plus merupakan faktor penguat. Perilaku PSN 3M Plus yang kurang menunjukkan bahwa masyarakat kurang terpajan dengan informasi kesehatan, baik segi kesadaran (awareness) atau ada pihak yang mengingatkan perlunya PSN (reminder). Beberapa studi, antara lain studi intervensi yang dilakukan Gomez, Suarez dan Cordenas di Mexico memberikan hasil bahwa upaya penyuluhan PSN terbukti efektif mengurangi habitat perkembangbiakan Ae.aegypti. ${ }^{7}$

Kegiatan promosi kesehatan harus dilaksanakan dengan menjangkau segenap lapisan masyarakat, sampai dengan terbentuk dan terpelihara partisipasi masyarakat. Dengan demikian, aktivitas pengendalian vektor DBD harus berbasis partisipasi masyarakat. Beberapa studi menunjukkan bahwa upaya pemberantasan sarang nyamuk cukup berhasil jika program diselenggarakan berlandaskan partisipasi aktif masyarakat. Promosi kesehatan yang dilaksanakan dengan mengedepankan peran serta masyarakat sangat efektif meningkatkan pengetahuan, persepsi, serta praktek pemantauan jentik nyamuk, sekaligus menurunkan indeks larva. ${ }^{8-10}$

\section{Koordinasi dan Sosialisasi}

Promosi kesehatan dalam pengendalian vektor DBD akan berlangsung dengan baik apabila di dalam masyarakat dan pemerintah telah terbentuk critical mass (massa kritis) yang memadai. ${ }^{11}$ Masa kritis tersebut terbentuk jika banyak orang merasa bahwa demam berdarah telah menjadi persoalan penting, menjadi musuh bersama yang harus diatasi secepatnya.

Hasil studi memperlihatkan bahwa koordinasi dan sosialisasi tidak berjalan dengan baik, sehingga perlu segera diperbaiki. Untuk itu, berbagai pihak yang paling bertanggung jawab terhadap DBD harus mampu dan perlu segera melakukan advokasi kepada walikota dan Dewan Perwakilan Rakyat Daerah (DPRD). Hal tersebut bertujuan untuk memposisikan program promosi kesehatan PSN 3M Plus sebagai program paling utama dalam pengendalian DBD. Upaya kuratif diletakkan sebagai rangkaian lima tingkat pelayanan pencegahan. Advokasi untuk menggerakkan partisipasi lintas sektor merupakan faktor penting terkait dengan sifat paternalistik dalam hubungan pemerintah-masyarakat. Masyarakat sering menunggu arahan dan petunjuk pemerintah. Sebagai contoh, ketika kecamatan belum menempatkan PSN 3M Plus sebagai metode utama mencegah DBD, masyarakat belum juga melakukannya.

Selanjutnya, sosialisasi perlu segera dan terus menerus dilakukan kepada segenap perangkat pemerintahan, di tingkat kelurahan sampai dengan tingkat kota. Partisipasi berbagai lembaga swadaya masyarakat perlu didorong guna menggerakkan kegiatan pengendalian vektor DBD pada tingkat rukun warga dan rukun tetangga (RW/RT). Untuk menjamin pelaksanaan di tingkat terendah rukun tetangga, serta tingkat pemerintahan (kelurahan, kecamatan dan satuan organisasi perangkat daerah/SOPD), maka setiap kelembagaan perlu menyusun perencanaan lokal (local planning) dengan pendampingan yang dilakukan oleh forum LSM. Dengan pendampingan, format perencanaan lebih terkendali, sehingga koordinasi dan sosialisasi dapat berlangsung lebih baik. 


\section{Keterbatasan Melakukan PSN 3M Plus}

Studi ini menunjukkan bahwa di dalam rumah tangga terjadi pembagian peran, yang menempatkan para suami pada aktivitas di luar rumah antara lain untuk mencari nafkah. Namun, para istri yang kebanyakan ibu rumah tangga mengenal pembagian wilayah tugas domestik suami dan istri. Oleh sebab itu, sejauh masih melakukan pekerjaan yang "dapat dikerjakan oleh ibu-ibu" para istri melakukannya. Namun, dari aktivitas 3M hanya menguras bak mandi atau menutup tempayan yang dapat dilakukan ibu-ibu, sementara habitat perkembangbiakan nyamuk sangat banyak. Oleh sebab itu, peran dari suami atau anggota keluarga lain termasuk anak-anak perlu ditumbuhkan.

\section{Kesimpulan}

Pengetahuan masyarakat tentang penyebab DBD dan mekanisme penularan virus dengue masih rendah. Sikap masyarakat terhadap PSN juga belum positif. Belum semua anggota masyarakat menganggap bahwa DBD adalah penyakit yang serius. Masyarakat lebih memilih melakukan fogging, karena tindakan yang seharusnya tidak mereka ketahui. Berbagai hal tersebut terjadi akibat kurangnya promosi kesehatan, belum baiknya koordinasi lintas sektor serta tidak efektifnya strategi yang dipilih.

\section{Saran}

Berdasarkan kesimpulan di atas, Pemerintah Kota Depok dengan dukungan dari DPRD perlu mengambil langkah-langkah strategis dan teknis dalam PSN 3M Plus sebagai pendekatan utama dalam mengendalikan penyakit demam berdarah. Beberapa langkah yang perlu segera dilakukan adalah meningkatkan alokasi anggaran promosi kesehatan untuk pengendalian vektor DBD, memfasilitasi kemitraan dan koordinasi internal pemerintah kota, serta antara pemerintah kota dan para pemangku kepercayaan serta masyarakat luas dalam menanggulangi DBD secara sistematis dan proporsional. Untuk memperluas akses informasi masyarakat dalam pengendalian vektor, dinas kesehatan kota perlu menata ulang strategi promosi dengan menyelenggarakan promosi kesehatan pengendalian vektor DBD melalui sekolah dan tempat kerja, selain memantapkan promosi kesehatan di komunitas.

\section{Daftar Pustaka}

1. Pai HH, Hong YJ, Hsu EL. Impact of a short term community-based cleanliness campaign on the sources of dengue vectors: an entomological and human behavior study. Journal of Environmental Health: Academic Research Library. 2006; 68: 6.

2. Kumar R, Krishnan SK, Rajashree N, Patil RR. Perceptions of mosquito borne diseases. Journal of Epidemiology and Community Health. 2003; 57, 5: 392.

3. Leon RB. Promoting health: evidences for a fairer society. Promotion \& Education. ProQuest Nursing \& Allied Health Source. 2001: 24.

4. Glanz K. Health behavior and health education: theory, research and practice. San Francisco: Josey-Bass Publishers; 1997.

5. Kasnodihardjo dan Sumengen. Aspek perilaku dalam kaitannya dengan penyakit demam berdarah di Kodya Sukabumi. Jakarta: Badan Litbangkes Depkes RI; 1988.

6. Green L, Kreuter MW, Deeds SG, Partridge KB. Health education today and the PRECEDE framework. Palo Alto, Calif.: Mayfield Publishing Co; 1979.

7. Gomez FE, Suarez CMH, Cardenas RC. Educational campaign versus malathion spraying for the control of aedes aegypti in Colima, Mexico. Journal of Epidemiology and Community Health. 2002: 56, 2: 148.

8. Therawiwat M, Fungladda W, Kaewkungwal J, Imamee N, Steckler A. Community-based approach for prevention and control of dengue hemorrhagic fever in Kanchanaburi Province, Thailand. Southeast Asian Jornal of Tropical Medicine and Public Health. 2005; 36, 6: 1439.

9. Crabtree, Ashencaen S, Wong CM, Mas'ud F. Community participatory approaches to dengue prevention in Sarawak, Malaysia. Human Organization. 2001: 60, 3; 281.

10. Yasumaro S, Silva ME, Andrighetti MTM, Macoris MDLG, Mazine $\mathrm{CAB}$, et al. Community involvement in dengue prevention project in Marilia, Sao Paulo, Brazil. Human Organization. 1998: 57, 2; 209.

11. Armstrong, Rebecca, Doyle J, Lamb C, Waters E. Multi-sectoral health promotion and public health: the role of evidence. Journal of Public Health [serial on the internet]. 2006; 28, 2: 168-172. 